\title{
A poluição na Baía de Guanabara e a emergência da pauta ambiental no jornal O Globo
}

\author{
The pollution in Guanabara Bay and the emergence of the environmental \\ agenda in O Globo newspaper
}

\section{La contaminación en la Bahía de Guanabara y el surgimiento de la agenda ambiental en el periódico $\mathrm{O}$ Globo}

Michel Misse Filho ${ }^{1, a}$

michelmisse93@gmail.com | https://orcid.org/oooo-0002-1485-7115

Raquel Paiva ${ }^{1, b}$

paivaraquel@hotmail.com | https://orcid.org/00oo-0001-8786-751X

${ }^{1}$ Universidade Federal do Rio de Janeiro. Rio de Janeiro, RJ, Brasil.

a Mestrado em Comunicação pela Universidade Federal do Rio de Janeiro.

${ }^{\text {b }}$ Doutorado em Comunicação pela Universidade Federal do Rio de Janeiro.

\section{Resumo}

Este artigo busca apresentar de que formas e sob quais circunstâncias a Baía de Guanabara pôde emergir como importante pauta jornalística ambiental. Analisando matérias do jornal O Globo entre as décadas de 1940 e 1970, período crucial para se entender a poluição daquele ambiente, identificamos a transformação de um referencial idílico da baía para a representação de um lugar de perigo. Nesse sentido, exploramos a importância que a saúde humana adquire para que esta pauta ambiental atingisse um alto patamar de noticialização, semelhantes aos níveis atuais. Refletimos, ainda, sobre as maneiras pelas quais a pauta ambiental pode ser construída, longe de síndromes comuns a esta especialidade jornalística, mas associada a marcos teóricos importantes do campo, como a imprescindibilidade do ativismo ecológico e a necessidade de ampliação do enfoque noticioso e abarcamento de conhecimentos de povos tradicionais.

Palavras-chave: Jornalismo ambiental; Baía de Guanabara; Poluição das praias; Comunicação; Meio ambiente. 


\begin{abstract}
This article seeks to present in which ways and circumstances Guanabara Bay could emerge as an important environmental journalistic agenda. Analyzing articles from the O Globo newspaper between the 1940 s and the 1970s, a crucial period to understand the pollution of the bay, we identified the changes of an idyllic reference point of the bay to represent a place of danger. In this sense, we explore the importance that human health acquires for the environmental agenda of the bay to reach levels of reporting similar to the current ones. We also reflect about how the environmental agenda can be built away from syndromes common to this journalistic field, but associated with important theories in the field, such as the indispensability of ecological activism and the need to expand the news focus and to encompass the knowledge of traditional people.
\end{abstract}

Keywords: Environmental journalism; Guanabara Bay; Beach pollution; Communication; Environment.

\title{
Resumen
}

Este artículo busca presentar de qué maneras y bajo qué circunstancia la Bahía de Guanabara podría emerger como una importante agenda periodística ambiental. Analizando artículos del periódico O Globo entre las décadas de 1940 y 1970, un período crucial para comprender la contaminación de la bahía, identificamos la transformación de un punto de referencia idílico de la bahía para representar un lugar de peligro. Em este sentido, exploramos la importancia que adquiere la salud humana para que la agenda ambiental de la bahía alcance niveles de informes similares a los actuales. También reflejamos las formas em que la agenda ambiental se puede construir a partir de síndromes comunes a este campo periodístico, asociada con importantes teorías en el campo, como la indispensabilidad del activismo ecológico y la necesidad de expandir el enfoque de las noticias y abarcar el conocimiento de las personas tradicionales.

Palabras clave: Periodismo ambiental; Bahía de Guanabara; Contaminación de playas, Comunicación; Medio ambiente.

Este artigo pertence ao dossiê Comunicação e Meio Ambiente.

Contribuição dos autores:

Concepção e desenho do estudo: Michel Misse Filho; Raquel Paiva

Aquisição, análise ou interpretação dos dados: Michel Misse Filho

Redação do manuscrito: Michel Misse Filho

Revisão crítica do conteúdo intelectual: Raquel Paiva

Declaração de conflito de interesses: não há.

Fontes de financiamento: não houve.

Considerações éticas: não há.

Agradecimentos/Contribuições adicionais: não há.

Histórico do artigo: submetido: 28 fev. 2020 | aceito: 08 maio 2020 | publicado: 30 jun. 2020.

Apresentação anterior: não há.

Licença CC BY-NC atribuição não comercial. Com essa licença é permitido acessar, baixar (download), copiar, imprimir, compartilhar, reutilizar e distribuir os artigos, desde que para uso não comercial e com a citação da fonte, conferindo os devidos créditos de autoria e menção à Reciis. Nesses casos, nenhuma permissão é necessária por parte dos autores ou dos editores. 


\section{Introdução}

Falar em meio ambiente no contexto fluminense é, inevitavelmente, abarcar o tema da Baía de Guanabara em algum momento. Parte constitutiva da gênese do Rio de Janeiro, a baía foi referenciada por poetas, pensadores, cientistas, pintores e viajantes e, de certa forma, é ainda a porta de entrada real e simbólica da cidade: região que engloba o porto e aeroporto; e histórico cartão-postal da região metropolitana. Principal símbolo de um Rio ainda voltado à sua região central, a velha baía recebia, no século XIX, os terapêuticos banhos de mar de Dom João VI na antiga Praia do Caju, hoje escondida nos aterros para o cemitério. Contornando a Zona Portuária, outras foram soterradas, como a Praia Formosa, Praia da Gamboa, Praia da Saúde e Prainha. Ao centro, as antigas praias de Santa Luzia e Boqueirão do Passeio eram das mais frequentadas, em uma época em que mais do que lazer e turismo, o banho de mar era assunto de saúde.

Afetada por um desenfreado processo de poluição de seu corpo hídrico que se intensificou ao longo do século XX, a baía tornou-se, aos poucos, figura carimbada do noticiário ambiental. Primeiramente e sob o ponto de vista documental, é a esta memória que nos dedicaremos neste artigo, utilizando basicamente a seção de 'matérias digitalizadas' do acervo digital do jornal O Globo (escolhido por sua ininterrupta circulação e boa instrumentalização do acervo), publicadas entre as décadas de 1940 e 1970. Ao mesmo tempo, o material será usado para analisar e discutir as formas com que se dá a irrupção de uma pauta ambiental no jornalismo, bem como, no caso da Baía de Guanabara, sua profunda relação com a saúde humana, em uma problemática eminentemente socioambiental e interdisciplinar.

Se em um primeiro momento vemos uma baía tratada de forma elogiosa nas referências que se apresentam, a transformação em torno de seu imaginário se deu, fundamentalmente, nas décadas de 1960 e 1970. Caberá refletirmos, a partir daí, sobre o desenrolar do processo de transformação de uma paisagem idílica a um ambiente contaminado, e por meio de quais nuances esta história foi narrada e noticiada.

A partir da consolidação, concomitante à poluição, da baía como pauta jornalística, figura central e protagonista das reportagens, o que se observa é uma abundância de matérias denunciativas dos problemas. Primeiramente vamos entender como foi o processo de popularização do banho de mar na cidade e a representação de uma baía ainda idílica no noticiário. Em seguida, abordaremos a solidificação da baía como pauta para buscar articular com noções do jornalismo ambiental, buscando abarcar outras dimensões possíveis de se tratar o tema, que recusem a separação entre assuntos ambientais e sociais, a fim de possibilitar uma ampliação do olhar sobre a questão ambiental no Brasil.

\section{A popularização das praias e a centralidade da Baía de Guanabara}

Se voltarmos às condições e hábitos do Rio de Janeiro antes do século XX, de certo se pode compreender sua proximidade e relação com o mar sob um aspecto mais portuário do que balneário. Desde o início da ocupação no antigo Morro do Castelo e no resto do atual Centro, as praias da região serviram ou como portos - aterradas ao longo do tempo, na atual Praça XV e na Zona Portuária - ou como depósito de dejetos humanos e animais.

A primeira obra da cidade com o objetivo de saneamento foi realizada em 1641, com a construção de uma vala na atual Rua Uruguaiana para drenagem da antiga lagoa de Santo Antônio, descarregando os esgotos e lixos da população diretamente na extinta Prainha, onde hoje é a Praça Mauá. Essa vala seria a primeira fonte pontual de significativa poluição das águas da Baía de Guanabara em um verdadeiro fosso aberto $^{1}$. Outras obras foram sucedidas, como a construção de um cano de pedra e cal que drenava as águas da mesma lagoa para a praia do Carmo, atual Praça XV, dando origem à Rua do Cano, hoje conhecida como Sete de Setembro. Apesar da pequena população carioca, a sujeira humana se juntava aos inúmeros cavalos, porcos e cabritos que andavam soltos pelas ruas. A limpeza dessas áreas só ocorreria, entretanto, graças à 
força da natureza e às fortes tempestades de verão, que arrastavam os dejetos para dentro da baía: "Naquele tempo já se dizia que a natureza era mãe e amiga, pois o homem sujava, o vento varria, a água lavava e o sol enxugava”.

Esses fatores ainda não representavam exatamente uma poluição hídrica 'sistêmica' na baía, mas a degradação da região era mais ampla que o espelho d'água. O início da colonização representou os primeiros indícios de agressão ambiental, a partir da extração de pau-brasil e da destruição de matas das ilhas da baía, bem como do seu entorno. Já no início do século XVII, junto ao ciclo da cana-de-açúcar, a pesca de baleias, abundantes durante o inverno, representou outra importante atividade econômica e uma grave perda ambiental. Delas se extraía o óleo para iluminação, as barbatanas para espartilhos e a carne para alimentação. A pesca duraria mais de duzentos anos, extinta apenas no início do século XIX, com o quase desaparecimento das baleias da baía.

As condições sanitárias da cidade naquele século eram péssimas, agravadas pelo aumento populacional após a vinda da família real em 1808. Ainda como uma prática legal, era comum o lançamento de águas sujas pela janela da casa, bem como a atuação dos chamados 'Tigres': barris de acúmulo de dejetos humanos, lançados pelos escravos em fossas abertas ou na beira das praias. Com o agravante das chuvas - que no século XVII limpavam a beira das praias, mas que agora faziam transbordar as fossas e valas -, os surtos de epidemias mortíferas eram frequentes. Após a morte de cinco mil pessoas decorrentes de uma epidemia de cólera em 1855 (a população da cidade à época não chegava a 270 mil habitantesi), o Rio assinou contrato com a companhia inglesa City para a construção de uma rede de serviços de esgotamento sanitário doméstico, tornando-se a terceira cidade do mundo a ter um sistema de esgoto ${ }^{\text {ii }}$.

É nesta época que, aos poucos, começa a se disseminar o hábito de tomar curtos banhos de mar. Até então, poucas pessoas, e em geral das classes baixas, tinham o costume de se banhar, e o faziam por razões mais lúdicas do que especificamente de saúde. A elaboração de reflexões respaldadas medicamente sobre as propriedades medicinais do banho chegariam a partir da metade do século, também como forma de evitar epidemias. Neste primeiro momento de popularização, o banho de mar era majoritariamente encarado como solução para problemas de saúde, longe ainda de ser um ambiente propício ao lazer².

Irônico, o escritor João do Rio dizia que a civilização comumente parte do mais difícil e complicado para o mais simples, criticando os antigos banhos com corda em cabines e nas barcas Ferry. Em 1911 o escritor saudou, assim, a ideia da construção de uma famosa casa de banhos junto à antiga praia do Boqueirão, em texto para a Gazeta de Notícias: "Foi o traço de união entre o mar e a urbes. [...] Um cheiro de alga, um cheiro sadio de mar era a própria atmosfera, e ouvia-se nas areias a voz das ondas quebrando-se”"

Destacam-se as casas de banho localizadas em praias da área central da cidade, banhadas pelas águas calmas da baía. A antiga praia de Santa Luzia, mais próxima ao centro e depois aterrada para as obras do aeroporto Santos Dummont, era uma das mais cheias e recebia banhistas de curta duração, já que, atendendo aos padrões de beleza de uma sociedade recém-saída da escravidão, os banhos não duravam mais do que 10 minutos, de forma a preservar a pele o mais branca possível. Já na virada do século XX e com a construção da Avenida Beira Mar, as praias do Flamengo e especialmente Botafogo passaram a receber os banhos da elite fluminense. Apesar da motivação medicinal, a essa altura o mergulho no mar já era também entendido como uma prática de lazer. É também da virada do século a profusão de clubes de regatas na cidade, transformando a baía também em lugar de prática desportiva.

A grande mudança, no entanto, veio com o início da ocupação de Copacabana. Localizada na parte externa à Baía de Guanabara, sua popularização representaria, a partir da terceira década do século, o

i Dados do IBGE de populações nos Censos Demográficos, segundo os municípios das capitais. Disponível em: $\underline{\text { https:// }}$ censo2010.ibge.gov.br/sinopse/index.php?dados=6\&uf=00 Acesso em 20 fev. 2020. 
início da apropriação da praia enquanto um local de sociabilidade, do convívio prolongado e do desfrute das belezas naturais, depois estendido às demais praias da cidade 4 . Ao mesmo tempo, o Rio começava a entrar lentamente no circuito do turismo internacional, e a década de 1920 abarcou importantes iniciativas na consolidação da atividade turística na cidade, vendo surgir os imponentes Hotel Glória e Copacabana Palace.

Demorou a ser consolidada a imagem de um Rio exótico, sensual e praiano. Nota-se, por exemplo, que o primeiro mapa especificamente turístico da cidade, produzido pelo governo em 1937, é orientado pelo Centro, com a imagem virada em 90 graus para a esquerda - a Zona Sul aparece isolada à oeste, e a orla da baía no centro/sul da imagem. As praias sequer eram destacadas como atrações, e o roteiro privilegiava as ruas, praças, parques, estátuas e edifícios da metrópole ${ }^{5}$.

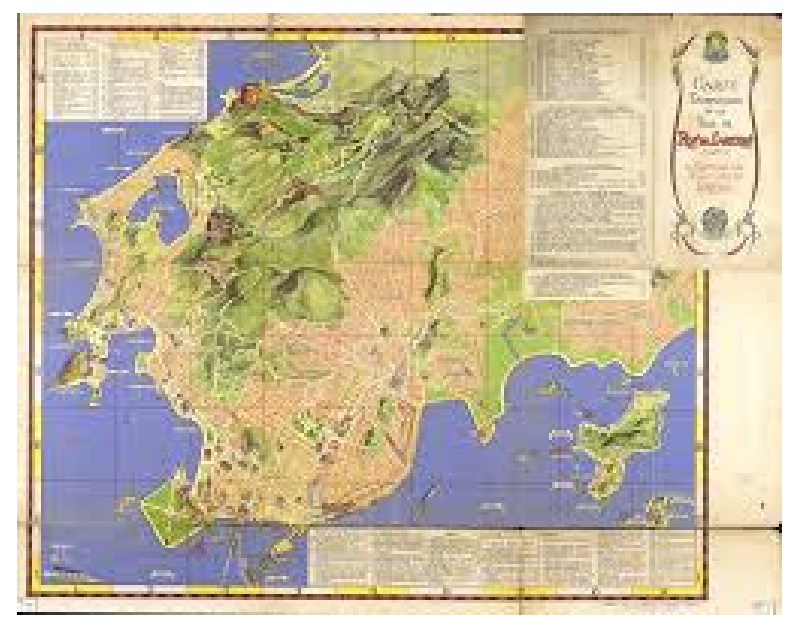

Figura 1 - Primeiro mapa especificamente turístico, de 1937 Fonte: Acervo da Fundação Biblioteca Nacional (1937).

A proeminência da baía à época é apontada por Castro: "As narrativas e imagens turísticas das primeiras décadas do século XX conduziam o olhar dos turistas a partir da entrada da Baía da Guanabara e do porto, por onde vinham os navios que traziam a maior parte dos visitantes da cidade. [...] O famoso guia inglês South American Handbook, em sua edição de 1932, informava que a baía da Guanabara, com seu 'soberbo brilho de cores, é a mais admirada do mundo', e que o 'famoso' cone de granito do Pão de Açúcar e o pico do Corcovado emprestam forte individualidade à cena. A chegada ao porto do Rio era 'um espetáculo sem igual, quer fosse de dia ou à noite"5.

Os primeiros momentos de inserção do Rio de Janeiro no circuito turístico e a propagação de seu imaginário exuberante em belezas naturais compreendem, assim, o início de nossa pesquisa documental, a partir do ano de 1940. Pesquisando matérias do jornal O Globo que contassem com a expressão 'baía de guanabara', notamos que a primeira década é recheada de referências idílicas, geralmente ditas por viajantes que atracavam na cidade. A baía em si, enquanto ambiente, não era a pauta principal das matérias, mas pano de fundo ou coadjuvante de outros assuntos. Também chama a atenção a quantidade de notas jornalísticas divulgando passeios organizados no recôncavo. É o caso, por exemplo, de uma excursão organizada em 1940 pelo Automóvel Clube em Magé, "a cidade a ser visitada (...) de onde se descortina a linda Baía de Guanabara”. As excursões continuaram durante os anos seguintes, evidenciando um aspecto da baía na época: era considerada um importante ponto de encontros turísticos e de lazer, em um Rio que apenas começava a crescer para as praias oceânicas.

Apesar da dita ascensão e popularização de Copacabana, a baía ainda assumia um papel de centralidade na metrópole, local de passeios oficiais e de ordem diplomática, especialmente durante a política da boa vizinhança da Segunda Guerra Mundial. Por exemplo, a visita do lorde John Davidson, alto funcionário do 
ministério britânico, pelos pontos pitorescos da baía; a excursão do general e futuro presidente americano Eisenhower pela Ilha de Brocoió; a filmagem do longa It's all true, de Orson Welles, na entrada da baía; e a recepção aos vitoriosos pracinhas, em 1945, ao longo da orla da baía.

A dita centralidade da Guanabara no imaginário dos estrangeiros pode ser verificada, ainda, em grande matéria ilustrada de 1946, que esmiúça os elogios do escritor André Siegfried às belezas da cidade como um todo, das florestas e montanhas à arquitetura, sem focar apenas na baía, como era praxe. O jornalista chama a atenção para um certo incômodo dos cariocas com o esquecimento das outras belezas da cidade: "Todos os turistas que nos visitam - e isso há mais de um século - cantam em prosa e em verso, principalmente em prosa, 'a beleza sem par da baía de Guanabara'. Os nossos repórteres de anteontem e de ontem, subindo ao convés dos navios recém-chegados desfechavam, à queima-roupa, aos passageiros mais importantes: 'Qual é a impressão de V.Exa. sobre a baía de Guanabara?'. Naturalmente, as respostas eram as esperadas: 'Admirável', 'Incomparável' etc. [...] Certas músicas, certas frases, certos versos geniais, à força de repetidos, de remoídos, chegam às fronteiras dos 'lugares comuns'. Todavia, não deixam de ser belos, geniais. A baía de Guanabara, os cariocas bem o sabem, porque a veem todos os dias, não teme confronto de beleza com as baías de Nápoles, Frisco ou do Bósforo. E além do mais, o carioca não gosta - e com toda razão - que se fale exclusivamente da baía, quando ela é apenas uma fração no conjunto das maravilhas do Rio"7.

Durante todas as décadas anteriores à de 1950, a palavra 'poluição' não foi citada nenhuma vez sequer em uma matéria junto com a expressão 'baía de guanabara'. Mesmo assim, é imperativo ressaltar que isso não significa a total inexistência de denúncias 'ambientais' no jornalismo até então. Um bom exemplo é uma matéria de 1927, de primeira página n’O Globo, que traz o título “A impiedade humana devastando a natureza! Árvores que choram e rochas que parecem ter coração - como vão sendo sacrificadas as ilhas da Guanabara"ষ $\mathrm{O}$ texto, ainda desprovido de características do jornalismo moderno, é uma ode à preservação das belezas naturais, mas ainda não contempla o assunto da poluição das águas.

O fato de não haver matérias que citem a poluição tampouco significa, todavia, que o espelho d'água era totalmente puro, ou que houvesse desconhecimento da sociedade à época. Sobre essa análise, nos ajuda mencionar um relatório de 1943 do Dr. Del Vecchio, da Quarta Divisão da Inspetoria de Águas e Esgotos, que muito antes dos jornais já alertava para a gravidade da situação: "Tomar um banho hoje em dia na praia de Botafogo é banhar-se numa verdadeira caldagem de micróbios patogênicos, todos de origem fecal, veiculados na água do mar"1. Outras reportagens isoladas, ao longo dos anos de 1960 já denunciando a situação, admitiam por sua vez que o problema vinha de décadas, mesmo que ainda localizado nas imediações do Caju e Ilha do Fundão.

Não nos cabe aqui, contudo, definir um momento exato em que a baía passou a ser poluída, como se a poluição fosse um estado fechado e inerte, que apareceu repentinamente, e a baía fosse uma piscina sem renovação de águas. O objetivo é compreender em que momentos, sob quais condições e de que maneiras a baía passou, na percepção social, a ser entendida, narrada e imaginada como um ambiente de poluição.

\section{A consolidação da baía como pauta ambiental: o 'verão da hepatite' em 1970}

Com as primeiras denúncias de poluição na imprensa, a Baía de Guanabara começa a se configurar como pauta recorrente, numa época de ainda inexistência de um campo especializado como o jornalismo ambiental. Das referências elogiosas e seu papel coadjuvante dos anos 1940 passa, paulatinamente, a virar protagonista das notícias. Na década de 1950, quatro matérias contam com as expressões 'poluição' e 'baía de guanabara' juntas.

O primeiro registro foi em 1957, com o título "O peixe está desaparecendo: aterros, águas poluídas ou envenenadas contribuirão para que se desertem as águas da Guanabara - um técnico aponta providências imediatas

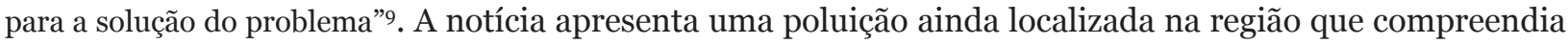


a recém-criada Ilha do Fundão, fruto de aterros que impossibilitaram a circulação das águas, e traz uma entrevista do professor de oceanografia, pesca e piscicultura, Antônio da Costa Pimentel sobre o assunto: "Cientistas do Instituto Oswaldo Cruz, mediante pesquisas, numa vasta zona da baía de Guanabara, determinaram as razões das poluições das águas, causas do desaparecimento da flora e fauna [...]. A leitura recente da impressionante súmula de trabalhos e observações a respeito da poluição das águas da enseada de Inhaúma e junto à ilha dos Pinheiros, no fundo da baía de Guanabara [...], trouxe nítidas e insofismáveis informações sobre esse mal que pode estender-se à maior superfície da baía de Guanabara!”.

\section{Peixe Está IDesaparecennall}

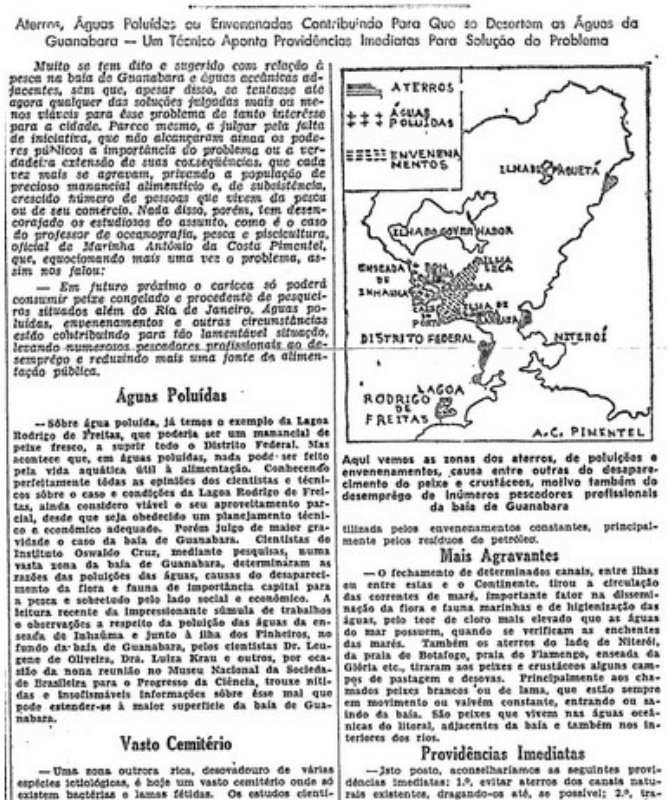

Figura 2 - Primeira matéria que cita a poluição na Baía de Guanabara Fonte: Acervo Digital do Jornal O Globo (1957).

A poluição, segundo a imagem da matéria, ocupava uma região restrita. $\mathrm{O}$ entrevistado pede ainda o tratamento de resíduos industriais e que se evitem novos aterros. Note-se que foi justamente nesse período que chegaram ao Rio as principais indústrias poluidoras da região, como a Refinaria Duque de Caxias (Reduc), cujas obras começaram em 1957; a Bayer do Brasil, de 1958; a Refinaria de Petróleo de Manguinhos, criada em 1954; e a Petroflex, antiga Fabor, unidade operacional da Petrobrás que entrou em funcionamento pouco depois, em $1962^{1}$.

Do ponto de vista do esgoto doméstico, os cerca de 274 mil habitantes do Rio de Janeiro em 1872, época das primeiras obras de esgotamento sanitário da City, já passavam dos 3,3 milhões em 1960i. Importante personagem técnico das primeiras matérias de denúncia ambiental da baía, o então diretor do Departamento de Esgotos Sanitários da Superintendência de Urbanização e Saneamento do Estado da Guanabara (Sursan), engenheiro Peixoto, mostrou em entrevista ao jornal que a relação entre o tamanho da rede de esgotos e a população era, no século XIX, de 1,10m por pessoa, índice que em 1959 estaria em apenas 0,27m. Já em 1961, o mesmo engenheiro vislumbra um certeiro e infeliz prognóstico sobre a situação da Baía de Guanabara para o futuro, caso medidas não fossem tomadas de forma urgente. $\mathrm{O}$ diagnóstico era inédito na imprensa até então: “A poluição afetará o uso das praias como balneários, a utilização de seus remansos para esquiagem e regatas, a pesca esportiva e profissional, a navegação em geral, inclusive o iatismo, e o efeito paisagístico, fonte de atração turística. No caso específico da baía de Guanabara, as suas águas vêm sendo inutilizadas, gradativa e constantemente, por despejos das redes de esgotos sanitários da cidade [...]; aterros de lixo; despejos da Refinaria de Manguinhos; rios que desembocam na baía e trazem despejos de indústrias" ${ }^{\text {. }}$. 
O grau de reflexão e detalhamento elaborado por Peixoto era, todavia, a exceção das matérias sobre a baía. É fundamental salientar, na realidade, que estes primeiros anos do histórico de matérias sobre a situação ambiental da baía tem seu foco quase que exclusivamente no comprometimento da fauna e flora da região. Boa parte das notícias também citava a poluição por óleo, resultado da frouxa legislação ambiental à época e a não punição dos que lavavam os tanques dos navios no interior da baíaiii .

O gráfico a seguir apresenta o número de matérias que continham 'poluição' e 'baía de guanabara' no jornal O Globo. Nota-se o boom registrado a partir da década de 1970, cujo patamar se mantém semelhante nas décadas seguintes:

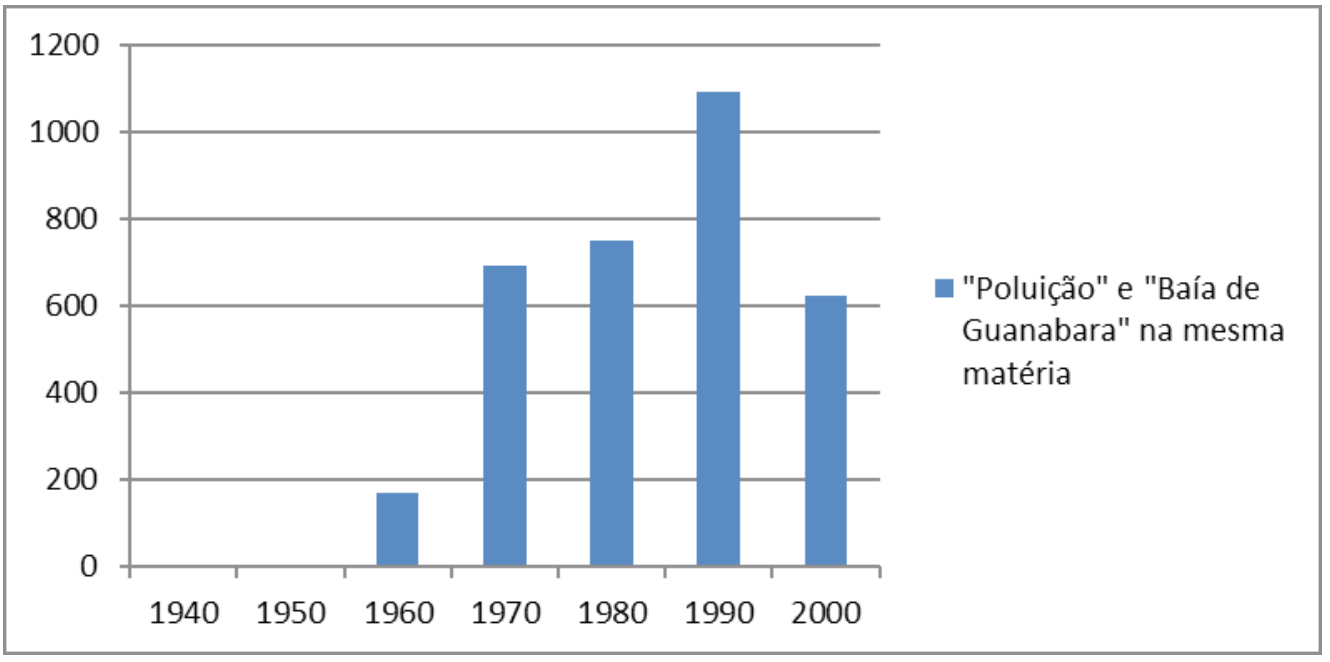

Figura 3 - 'Poluição' e 'Baía de Guanabara' na mesma matéria, de 1940 a 2000

Fonte: Os autores (2019).

A análise das matérias ao longo destas décadas nos mostrou que o foco predominante no comprometimento da fauna e flora da região durou até a segunda metade da década de 1960, em matérias ainda distantes do leitor, cuja construção se dava, quase que exclusivamente, em torno das fontes oficiais do governo. Esmiuçando o gráfico anterior, percebemos que a maior inflexão de matérias sobre poluição na baía se deu, mais especificamente, na virada para os anos de 1970.

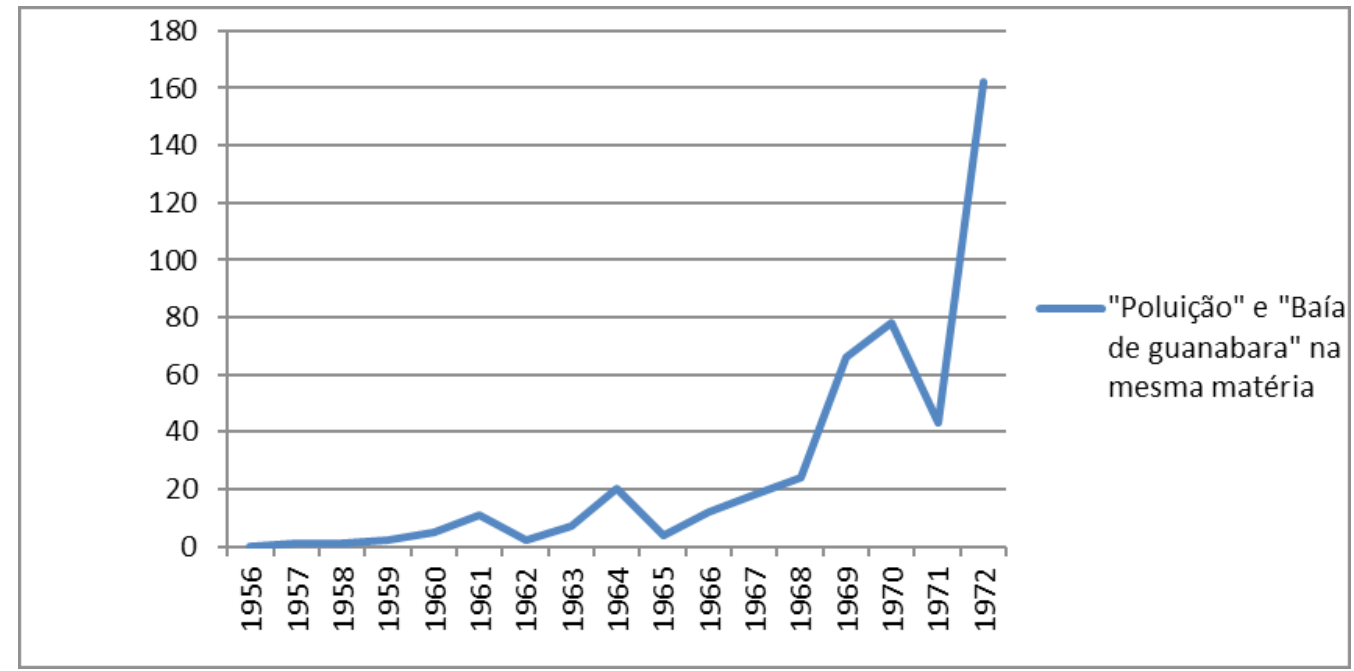

Figura 4 - 'Poluição' e 'Baía de Guanabara' na mesma matéria, de 1956 a 1972 Fonte: Os autores (2019).

iii O Brasil, à época governado por Getúlio Vargas e em plena crise que culminaria em seu suicídio, se ausentou da Convenção de Londres em maio de 1954. Foi um dos primeiros encontros ambientais, proibindo a descarga persistente de óleo em determinadas zonas, como medida de prevenção à poluição dos mares. 
A grande transformação destes anos foi a expansão de uma pauta estritamente 'ambiental', relativa à fauna e flora, passando a abordar o perigo a que os banhistas estariam expostos quanto à saúde. Tudo começou com a suspeita de que surtos de hepatite na cidade estariam associados ao banho de mar em praias poluídas. A informação, no entanto, era recorrentemente desmentida pelos órgãos oficiais.

Fora das análises quantitativas (o ano de 1972 registrou o recorde até então de 162 matérias), entendese que o principal destaque compreende a virada da década, no verão de 1970. O gancho jornalístico já vinha de dois anos antes: às vésperas do Réveillon de 1968, teria início a controvérsia que, pouco depois, elevaria a discussão para outro patamar. A confusão sobre se o banho de mar em determinadas praias da baía ofereceria perigo (ou não) aos banhistas invadiu os jornais naqueles anos e, em um primeiro momento, O Globo reproduziu a posição do governo: "Saúde Pública: praia de Botafogo não oferece perigo aos banhistas" ${ }^{11}$. No dia seguinte, uma reportagem anuncia o Rio de Janeiro "sob ameaça de hepatite no verão"12, focando especialmente na Ilha do Governador e Praia de Ramos. A Superintendência de Saúde Pública do Estado (Susape), por sua vez, negou haver perigo de surto de hepatite. A relação direta entre hepatite e poluição de águas ainda não era 'confirmada' cientificamente.

A controvérsia começa por meio de matérias da imprensa que ora denunciam a poluição e suas mazelas, ora trazem posições oficiais de órgãos do Estado ou de estudos desmentindo, relativizando, ou prometendo em curto prazo a solução dos problemas mencionados na denúncia. Logo em janeiro de 1968, a notícia "Água de praia não transmite doenças" trouxe exames do Instituto de Engenharia Sanitária (IES) da SURSAN, em que não foi acusada a existência de salmonelas nas águas da Guanabara. Quanto à hepatite, o diretor do Instituto, José de Santa Rita, afirmou que "ainda é discutível no mundo inteiro se a hepatite pode ser contraída nas praias". Segundo ele, o principal problema das praias cariocas era de ordem estética, "o que só poderá ser corrigido com grandes obras de engenharia e a aplicação severa da legislação já existente sobre a poluição"13.

Ao final de janeiro daquele ano, mais uma entre muitas matérias denuncia a destruição de peixes e plantas do fundo da baía em decorrência da poluição. Ao analisar as reportagens, abrem-se dois tipos de efeitos negativos da poluição: um relativo à fauna e flora - declarado como certo e sem aparentes contestações -, e o outro relativo à saúde humana, objeto de disputa na arena da opinião pública. Apesar do aumento de reportagens, a poluição ainda não configurava um entrave para o carioca frequentador das praias. Em fevereiro de 1968, a matéria "Um quilômetro de desconforto para o banhista"14 expunha a situação da praia de Ramos que, mesmo poluída, permanecia lotada nos dias de sol: "A praia de Ramos, com aproximadamente um quilômetro de extensão, é mais importante do que muitas outras mais extensas. Ali se concentra o maior número de pessoas por metro quadrado e, aos domingos, a areia fica totalmente tomada, obrigando muitos banhistas a permanecerem dentro da água. [...] Segundo o Instituto de Engenharia Sanitária da SURSAN, a poluição das águas da baía de Guanabara, nas proximidades de Ramos é a mais grave de todas as praias cariocas. Por isso, 'não é aconselhável' tomar banho ali, mas nada tem sido feito para contornar tal situação"14.

Os anos seguintes permanecem com a controvérsia, pendendo mais para o lado da poluição e o risco de doenças. Anuncia-se que até a Administração Nacional da Aeronáutica e Espaço (Nasa, na sigla em inglês) viria "medir com infravermelhos as temperaturas da baía de Guanabara" 15 e que um "colar flutuante norueguês pode limpar praias do Rio"16. Já a reportagem “Carioca come mexilhões que já causaram mortes"17 esmiúça o problema de contaminação de mexilhões retirados da Baía de Guanabara.

É no verão de 1970, no entanto, que a forma como a Baía de Guanabara era pautada pelos jornais se transforma substancialmente. A discussão entre poluição e contração de doenças se acirrou com uma extensa matéria d'O Globo, publicada em 7 de janeiro, mostrando os dados de substâncias encontradas nas águas cariocas coletadas pelo jornal e analisadas por um laboratório privado. É a primeira matéria do tipo, com uma tabela detalhada informando o conteúdo encontrado e o grau de poluição de todas as praias do Rio com o título: "Metade das praias poluídas" ${ }^{18}$. Entre as poluídas, com exceção do posto seis de Copacabana, todas se localizam no interior da Baía de Guanabara. A praia de Botafogo era a única que estava interditada, 
e o jornal provoca: "para as autoridades todas as outras praias do Rio estão em perfeitas condições de ser frequentadas por crianças e adultos, uma vez que não estão interditadas"18.

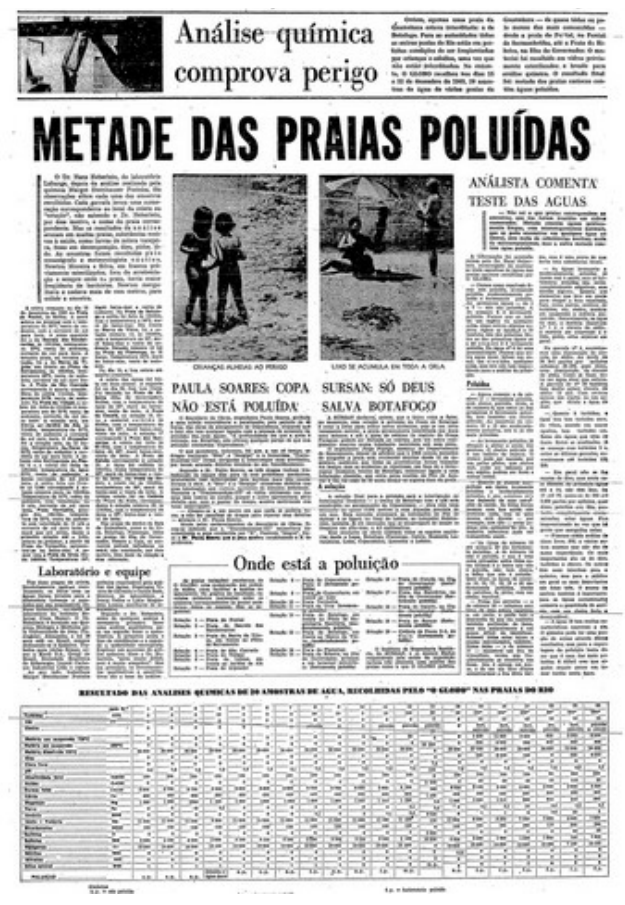

Figura 5 - No verão de 1970, a primeira grande matéria com testes de laboratório Fonte: Acervo Digital do Jornal O Globo (1970).

No dia seguinte, outra matéria traz uma mudança completa de construção narrativa do tema. Em vez de se limitar às recorrentes entrevistas com técnicos do governo, foram publicadas diversas fotos, em que a principal expunha uma mãe ao lado dos filhos na praia: "A maioria das mães cariocas não faz ideia do perigo a que estão expostos seus filhos"19 é a legenda da imagem. Médicos foram entrevistados e atribuíram à poluição das águas o aumento do número de casos de hepatite na Ilha do Governador. Ao mesmo tempo, banhistas se mostraram surpresos com a novidade que era colocada na vida do carioca, ainda tão acostumado a frequentar as praias da baía: "A maioria dos banhistas cariocas revelava à reportagem que não julgava fosse tão grande o perigo a que estavam expostos, demonstrando disposição de procurar agora locais menos insalubres. [...] Muita gente ficava surpresa: 'Ué, não era só Botafogo?'. [...] Principalmente na Ilha do Governador, as pessoas indagavam: 'Se todas as examinadas aqui da Ilha estão poluídas, será que todas não podem ser frequentadas?' [...] 'Eu estou aqui no Rio a passeio, sou de São Paulo. Bem, eu achei que esta praia era muito suja e não pretendia frequentá-la, mas vi que as senhoras que moram aqui trazem os filhos a ela e pensei que não era nociva à saúde. Agora vou procurar outra”'”. 


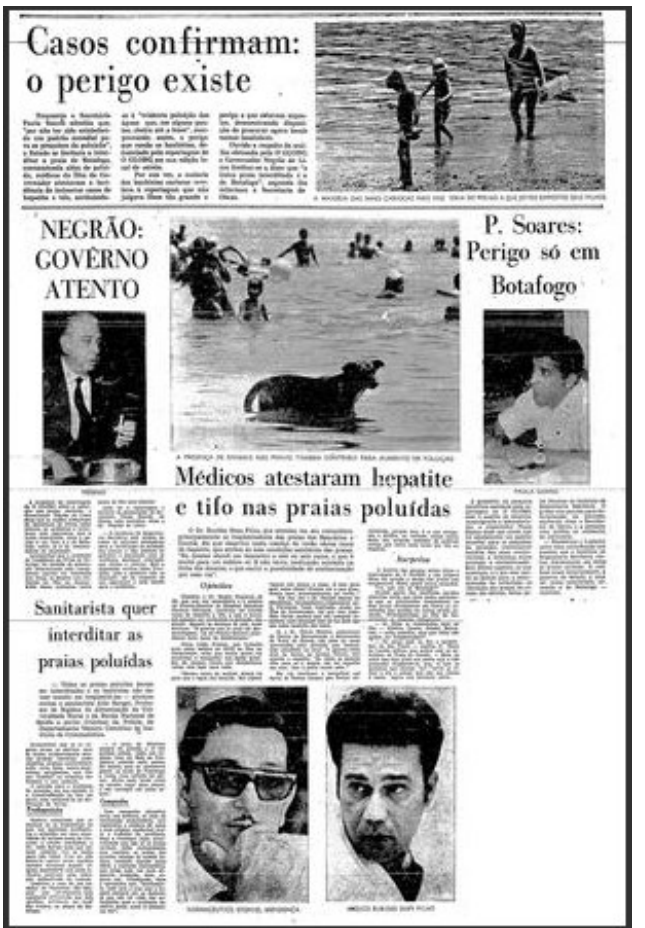

Figura 6 - A noção de perigo à saúde humana associada à poluição das praias Fonte: Acervo Digital do Jornal O Globo (1970).

A importância desta matéria se dá pela mudança de construção da própria reportagem. Foi, provavelmente, a primeira mais próxima do leitor, com entrevistas que não fossem de técnicos do governo, contando com fotos de banhistas e assumindo um tom de denúncia inédito na relação entre poluição e a saúde humana - com o passar dos anos, o Poder Público aceitou o argumento do risco à saúde. Em um exercício imaginativo, pode-se supor que só a pauta estritamente ambiental, como o desaparecimento da fauna e flora da região, talvez não tivesse força suficiente para elevar a discussão da poluição na baía ao nível em que se encontrou após essas matérias, e que até hoje permanece: as médias de matérias sobre o assunto nas décadas subsequentes mantêm-se semelhantes à da década de 1970.

Curiosamente, se foi a relação com a saúde que fez com que se popularizassem os banhos de mar na cidade (com a consequente valorização do Rio como balneário idílico e de belezas naturais), é justamente por questões de saúde pública que a Baía de Guanabara se torna, jornalisticamente falando, talvez a primeira grande pauta ambiental do estado e das mais importantes em âmbito nacional.

\section{O caso da Baía contextualizado na formação do jornalismo ambiental brasileiro}

Para fins analíticos, podemos decompor alguns conceitos fundamentais do jornalismo. Ao contrário da literatura ficcional, a narrativa jornalística contém um tipo de valor 'real', que é justamente a sua capacidade de representar os fatos 'brutos' por meio dos acontecimentos jornalísticos. Segundo Sodrée ${ }^{20}$ o acontecimento pressupõe um tipo de ruptura, e por isso é intrinsecamente ligado à narrativa, no momento em que a informação constrói um tipo de enredo, uma fabulação a partir do fato bruto, transformando a 'factualidade' da vida, que é ausente de enredo e composta exclusivamente de coincidências, repetições e eventos inesperados. O enquadramento - seja de natureza política, estética ou ética -, por sua vez, permite ao ator social "descrever, interpretar ou categorizar as situações que se lhe afiguram como problemáticas. Por meio dele, um problema social é suscetível de converter-se em problema público”20. 
A partir de determinados enquadramentos e construções narrativas, a poluída baía pôde ser entendida como um problema público. Mesmo que suas águas fossem o destino final de toneladas de esgoto já há muito tempo, apenas na década de 1950, e ainda de forma incipiente, este fato bruto (o lançamento de esgoto in natura) começou a ser tratado como um acontecimento, penetrando as páginas d'O Globo pela primeira vez e, consequentemente, ganhando o status de um problema público. Reiteramos, assim, o necessário alinhamento entre a percepção de um problema e as referências e valores que englobam uma sociedade, como sugere Gusfield: “os problemas humanos não brotam, prontos e anunciados, dentro da consciência do observador. Mesmo para reconhecer uma situação como perigosa requere-se um sistema de categorização e definição de eventos"21.

É provável, portanto, que as análises desenvolvidas sobre as matérias digam menos a respeito das características físico-químicas da baía à época do que propriamente nos diz acerca do jornalismo e da percepção da sociedade naquele momento sobre essas questões. Afinal, não se pode desconsiderar a enorme influência de eventos internacionais e a ascensão do pensamento ambientalista neste momento: o contexto histórico de aumento vertiginoso das matérias de poluição é exatamente o de ascensão das pautas e movimentos ambientalistas, na esteira da Conferência da Biosfera da Organização das Nações Unidas para a Educação, a Ciência e a Cultura (Unesco) em 1968 e, ainda mais importante, a Conferência de Estocolmo da Organização das Nações Unidas (ONU), realizada em 1972.

No momento em que o lançamento indevido de esgoto in natura passa a ser interpretado como poluição de um corpo hídrico; a fumaça industrial é entendida como vetor de poluição atmosférica; ou a pesca predatória é associada ao extermínio de espécies, enfim, quando essas dimensões se tornam questões e são problematizadas pela sociedade, parece-nos que surge, aí, a oportunidade de um novo nicho jornalístico, neste caso, o ambiental. Não à toa as raízes de um jornalismo ambiental brasileiro são encontradas nos anos de 1970, com origens no jornalismo científico, mas na esteira dos movimentos ambientalistas que confluíam com o início de um processo de redemocratização. Já a consolidação do jornalismo ambiental enquanto especialização temática, como sugere Belmonte ${ }^{22}$, vem dos preparativos para a conferência Eco92, sediada no Rio de Janeiro. Também não é coincidência observarmos que, até hoje, o recorde anual de matérias com 'poluição' e ‘baía de guanabara' n'O Globo aconteceu justamente em 1991, com 238 registros, às vésperas da conferência e sob influência das promessas de despoluição.

A análise do caso da baía também parece corroborar uma das principais hipóteses acerca da construção da pauta ambiental nos jornais: o meio ambiente vira notícia, geralmente, quando está em perigo. Ao analisar a formação do jornalismo ambiental brasileiro, é também imperativo que se descole de algumas características que o fragilizam, como a reiterada fragmentação do olhar jornalístico, retirando a reportagem de uma análise sistêmica e de sua perspectiva interdisciplinar. Nesse sentido, o processo de segmentação jornalística em cadernos e editoriais reduz a cobertura ambiental a um determinado olhar, seja ele econômico, científico ou político ${ }^{23}$. É igualmente comum, junto ao dito olhar fragmentado, a pouca diversificação das vozes e concentração dos tipos de discursos expostos na reportagem, em um jornalismo que parece refém das fontes oficiais ${ }^{24}$.

Adicionam-se aí outras "síndromes" do jornalismo ambiental, demonstradas nas pesquisas de Bueno ${ }^{23}$, como "a tentativa de despolitização do debate ambiental, desvinculando-o de uma vertente técnica"; a "lattelização das fontes" nos jornais, notadamente científicas; a tentativa de limpeza de imagem de empresas poluidoras por meio do "marketing verde"; e a espetacularização da tragédia ambiental, com a procura do inusitado e o recurso ao sensacionalismo.

Ao falarmos da formação do jornalismo ambiental, precisamos, contudo, demarcar o que seria a simples cobertura de assuntos de meio ambiente. Há um entendimento neste campo de que o jornalismo ambiental, mais do que abordar assuntos de meio ambiente, deve ser necessariamente engajado, envolvido e comprometido com o assunto, tratando-o de um ponto de vista assumidamente 'parcial', em oposição 
à pretensa neutralidade que norteia um determinado tipo de visão jornalística. Nesse sentido, o ativismo ecológico é imprescindível para que surja o jornalismo ambiental, que dificilmente brotaria “do nada"22.

Uma possível concepção de jornalismo ambiental integrado e sistêmico vem sendo buscada em pesquisas do campo por meio de conceitos como o de "complexidade" ${ }^{25} \mathrm{e}$ o de "ecologia dos saberes" ${ }^{26}$, de forma a ampliar o reduzido enfoque das notícias ambientais e diversificar as fontes jornalísticas a que as matérias se submetem ${ }^{24}$. São abarcados, portanto, os conhecimentos de povos indígenas, das florestas, ribeirinhos, caiçaras, trabalhadores urbanos, agricultores familiares, pescadores artesanais, em toda vasta gama de saberes existentes no território nacional, para além das predominantes visões técnico-científicas ou políticas.

\section{Considerações finais}

Neste artigo compreendemos as condições e a maneira com que a pauta da poluição na Baía de Guanabara emergiu e pôde tornar-se, como é até hoje, assunto corriqueiro no jornalismo ambiental brasileiro. A baía, que por conta dos saudáveis banhos de mar havia se aproximado do cotidiano do carioca na virada do século XX - deslocando-se de ambiente portuário para também balneário -, teria seu imaginário invertido, desta vez destacada pela mídia como lugar perigoso à saúde.

Com uma demanda ainda pequena por assuntos estritamente ambientais à época das primeiras matérias de poluição, a configuração de um perigo à saúde humana fez com que o assunto tomasse outras proporções, já na década de 1970, em um momento de atenção global aos assuntos ecológicos. É também interessante notar como o deslocamento editorial de abordagem da baía, confluindo naquele momento aspectos ambientais e de saúde $\mathrm{u}^{\mathrm{iv}}$, transformou-se em importante pauta do jornalismo fluminense mesmo durante os mais duros anos de censura da Ditadura Militar. Cabem, ainda, futuras interrogações quanto às implicações daquelas matérias, que pautavam de forma negativa um dos principais símbolos do país, no auge do ufanismo militar, sintetizado justamente em obras grandiosas como a Ponte Rio-Niterói, construída sobre as águas da Guanabara entre 1969 e 1974, e alterando definitivamente aquele ambiente.

Outros períodos de agitação da pauta da Baía de Guanabara (e isso fica como horizonte para outras pesquisas) incluem crimes ambientais como o derramamento de óleo da Reduc em janeiro de 2000, bem como o momento que antecede a Olimpíada de 2016, com o não cumprimento das promessas de despoluição. No entanto, reforçamos a importância de se explorar e pesquisar a pauta ambiental em situações de 'cotidiano' jornalístico, no enfoque preventivo e denunciativo, isto é, sem estar condicionada às eventuais tragédias ambientais.

Torna-se fundamental, desta forma, levar em conta a necessidade de o jornalismo ambiental abranger temas diversos, sob um olhar de inerente interdisciplinaridade e em conjunto com a pauta social. Enxergar, portanto, a discussão da problemática socioambiental a partir de um modelo mais integrativo ${ }^{27}$. No caso da Baía de Guanabara, mais do que pautar os perigos, tragédias e denúncias, abre-se a oportunidade de redimensionar o tema e abordá-lo levando em conta as potencialidades daquele local: a despoluição da baía enquanto pauta de saúde, lazer, turismo, esporte, transporte, valorização imobiliária e desconcentração econômica.

iv O imbricamento entre as áreas ambiental e de saúde desdobrou-se em ampla bibliografia ${ }^{28-31}$, e acaba por também influenciar as abordagens do jornalismo ambiental. 


\section{Referências}

1. Coelho V. Baía de Guanabara: uma história de agressão ambiental. Rio de Janeiro: Casa da Palavra; 2007.

2. Melo V. O Mar e o Remo no Rio de Janeiro do Século XIX. Rev Estudos Históricos [Internet]. 1999 [citado em 2020 maio 19];23:41-71. Disponível em: http://bibliotecadigital.fgv.br/ojs/index.php/reh/ article/view/2088.

3. Gaspar C. Orla carioca: história e cultura. São Paulo: Metavídeo SP; 2004.

4. Feijão R. As praias cariocas no início do século XX: sociabilidade e espetáculos do corpo. Escritos [Internet]. 2013 [citado em 2020 maio 19];7(7):229-247. Disponível em:http://escritos.rb.gov.br/ numero07/escritos\%207 09 as\%20praias\%20cariocas.pdf.

5. Castro C. Narrativas e imagens do turismo no Rio de Janeiro. In: Velho G., organizador. Antropologia urbana: cultura e sociedade no Brasil e em Portugal. Rio de Janeiro: Jorge Zahar; 2006. p. 80-86.

6. Excursão do Automóvel Club. O Globo. 1940 jul. 25;7.

7. Se há sete maravilhas no mundo... Uma frase de André Siegfried em face dos mil e um atrativos da terra carioca. O Globo. 1946 dez. 10;6.

8. A impiedade humana devastando a natureza! Árvores que choram e rochas que parecem ter coração como vão sendo sacrificadas as ilhas da Guanabara. O Globo. 1927 nov. 2;1.

9. O peixe está desaparecendo: aterros, águas poluídas ou envenenadas contribuirão para que se desertem as águas da Guanabara. O Globo. 1957 ago. 1;3.

10. Terrível ameaça sobre a Baía de Guanabara. O Globo. 1961 abr. 28;17.

11. Saúde pública: praia de Botafogo não oferece perigo aos banhistas. O Globo. 1967 dez. 27;5.

12. Sob ameaça de hepatite no verão. O Globo. 1967 dez. 28;11.

13. Água de praia não transmite doenças. O Globo. 1968 jan. 18;18.

14. Um quilômetro de desconforto para o banhista. O Globo. 1968 fev. 2;5.

15. NASA virá medir com infravermelhos temperaturas da Baía de Guanabara. O Globo. 1969 jun. 5;12.

16. Colar flutuante norueguês pode limpar praias do Rio. O Globo. 1969 ago. 22;5.

17. Carioca come mexilhões que já causaram mortes. O Globo. 1969 jul. 10;6.

18. Metade das praias poluídas. O Globo. 1970 jan. 7;7.

19. Casos confirmam: o perigo existe. O Globo. 1970 jan. 8;13.

20. Sodré M. A narração do fato: notas para uma teoria do acontecimento. Petrópolis, RJ: Vozes; 2009.

21. Gusfield J. The culture of public problems: drinking-driving and the symbolic order. Chicago: University of Chicago Press; 1981.

22. Belmonte R. Uma breve história do jornalismo ambiental brasileiro. Rev. Bras. História Mídia [Internet]. 2017 [citado em 2020 maio 19];6(2):110-125. Disponível em: https://revistas.ufpi.br/index.php/rbhm/ article/view/6656/3817.

23. Bueno W. Jornalismo ambiental: explorando além do conceito. Desenvolvimento e Meio Ambiente [Internet]. 2007 jan./jun. [citado em 2020 maio 19];15:33-44. Disponível em:https://revistas.ufpr.br/ made/article/view/11897/8391.

24. Girardi I. et al. Caminhos e descaminhos do jornalismo ambiental. Comum Soc [Internet]. 2012 [citado em 2020 maio 19];34(1):131-152. Disponível em: https://www.metodista.br/revistas/revistasims/index. php/CSO/article/view/ 2972/3136.

25. Morin E. Introdução ao pensamento complexo. Porto Alegre: Sulina; 2015.

26. Santos B. Para além do pensamento abissal: das linhas globais a uma ecologia dos saberes. Novos Estudos [Internet]. 2007 [citado em 2020 maio 19];79:71-94. Disponível em: http://www.scielo.br/ scielo.php?script=sci arttext\&pid=S0101-33002007000300004\&lng=en\&nrm=iso. 
27. Fernandes V, Sampaio C. Problemática ambiental ou problemática socioambiental? A natureza da relação sociedade/meio ambiente. Desenvolvimento e Meio Ambiente [Internet]. 2008 [citado em 2020 maio 19];18:87-94. Disponível em: https://revistas.ufpr.br/made/article/view/13427/9051.

28. Freitas C. Problemas ambientais, saúde coletiva e ciências sociais. Ciênc Saúde Coletiva [Internet]. 2003 [citado em 2020 maio 19]8(1):137-150. Disponível em: https://www.scielo.br/pdf/csc/v8n1/a11v08n1. pdf.

29. Porto M, Rocha D, Finamore R. Saúde coletiva, território e conflitos ambientais: bases para um enfoque socioambiental crítico. Ciênc Saúde Coletiva [Internet]. 2014 [citado em 2020 maio 19]; 19(10):40714080. Disponível em: https://www.scielo.br/pdf/csc/v19n10/1413-8123-csc-19-10-4071.pdf.

30. Rigotto R, Augusto L. Saúde e ambiente no Brasil: desenvolvimento, território e iniquidade social. Cad. Saúde Pública [Internet]. 2007 [citado em 2020 maio 19];23:S475-S485. Disponível em: https://www. scielo.br/pdf/csp/v23s4/02.pdf.

31. Camponogara S, Kirchhof A, Ramos F. Uma revisão sistemática sobre a produção científica com ênfase na relação entre saúde e meio ambiente. Ciênc Saúde Coletiva [Internet]. 2008 [citado em 2020 maio 19] 13(2):427-439. Disponível em: https://www.scielosp.org/pdf/csc/2008.v13n2/427-439/pt. 